\title{
MENULIS SEBAGAI BENTUK PELESTARIAN BUDAYA LOKAL
}

\author{
Santi Susanti ${ }^{1}$ \\ ${ }^{1}$ Fakultas Ilmu Komunikasi Universitas Padjadjaran \\ Jalan Raya Bandung-Sumedang Km 21, Jatinangor, Indonesia \\ Email: santisusanti2202@gmail.com
}

Diterima : 31 Januari 2018

Disetujui : 15 Februari 2018

Diterbitkan : 28 Februari 2018

\begin{abstract}
Abstrak
Bahasa Sunda merupakan salah satu hasil kebudayaan lokal yang turut berkontribusi pada kekayaan bahasa Indonesia, juga sebagai identitas bagi suku Sunda yang melahirkan bahasa tersebut. Keberadaannya perlu dilestarikan agar tidak tergerus dinamisnya perubahan budaya masyarakat. Kekhawatiran tidak digunakannya lagi bahasa Sunda sebagai alat komunikasi muncul, terutama jika dikaitkan dengan data mengenai berkurangnya pengguna bahasa Sunda, serta kenyataan yang menunjukkan banyaknya keluarga Sunda yang tidak lagi mengajarkan bahasa Sunda kepada anak-anaknya. Agar identitas tersebut tidak hilang, maka penggunaan bahasa Sunda sebagai alat komunikasi dan bagian budaya lokal harus terus dilakukan. Peran pemilik bahasa dalam menjaga keberlangsungan penggunaannya sangat berarti. Salah satu upaya yang dilakukan adalah melalui karya tulis bertema kasundaan dan atau ditulis dalam bahasa Sunda. Tulisan ini bertujuan mengungkapkan upaya sejumlah penulis di Kota Bandung melestarikan budaya Sunda melalui tulisan. Penelitian ini menggunakan metode kualitatif-fenomenologi dan data diperoleh melalui wawancara mendalam kepada 8 informan, observasi, serta studi pustaka. Informan dipilih melalui teknik purposive sampling, agar bisa menggambarkan tujuan penelitian. Hasil penelitian menunjukkan, pelestarian budaya melalui tulisan berbahasa Sunda didorong oleh idealisme sebagai pemilik bahasa untuk memertahankan bahasa Sunda agar tidak hilang dan masih diketahui oleh generasi penerus. Bentuk tulisan dan media yang dipilih beragam, sesuai kemampuan penulis untuk menyampaikannya.
\end{abstract}

Kata kunci: Penulis Sunda, media komunikasi, idealisme, pelestarian bahasa Sunda.

\begin{abstract}
Sundanese is a part of local culture that contribute to the wealth of Bahasa Indonesia, as well as an identity for the Sundanese whose own the language. Preservation of its existence needs to be done in order to avoid its lost by cultural dynamic changes of society. Concerns about not using Sundanese as a communication tool emerges, as data showed the decline of Sundanese speakers and the fact that a number of Sundanese families no longer teach Sundanese to their children. To keep the identity remain to exist, the use of Sundanese in communication as a part of local culture should be continued. The role of language owners in maintaining its use is very meaningful. One of the efforts made through written works about Sundanese and/ or written in Sundanese. This paper aims to reveal the role of writers in Bandung preserve Sundanese culture through writing. This research uses qualitativephenomenology method and data obtained through in-depth interviews with 8 informants, observation, and literature study. Informants were chosen through purposive sampling technique. The results show, preservation of Sundanese culture through Sundanese writing is driven by idealism as the language owner to maintain the Sundanese existence and still
\end{abstract}


known by next generation. Writing forms and media are selected vary, according to the ability of authors to deliver it.

Keywords: Sundanese writer, medium of communication, idealism, preservation of Sundanese language

\section{PENDAHULUAN}

Salah satu unsur budaya yang selalu ada di setiap negara adalah bahasa. Menurut Budhisantoso (1990: 4), bahasa memiliki peran sangat besar dalam membangun komunikasi, karena bahasa merupakan alat komunikasi manusia sekaligus milik manusia yang berharga. Dengan bahasa, orang bisa melestarikan budaya dari satu generasi ke generasi berikutnya. Bahasa juga merupakan identitas suatu bangsa atau masyarakat. Bahasa menunjukkan bangsa. Melalui bahasa, identitas daerah asal seseorang akan dengan mudah diketahui. Apakah seseorang itu orang Indonesia, orang Sunda, orang Batak, orang Minang atau orang Jawa, dapat diketahui ketika mendengarkan bahasa yang disampaikan saat berkomunikasi dengan orang dari wilayah yang sama.

Bahasa di nusantara ini merupakan warisan nilai budaya masa lalu (intangible heritage) yang berasal dari budaya-budaya lokal, meliputi: tradisi, cerita rakyat dan legenda, bahasa ibu, sejarah lisan, kreativitas (tari, lagu, drama pertunjukan), kemampuan beradaptasi dan keunikan masyarakat setempat (Galla, 2001: 12).

Keragaman suku bangsa di Indonesia, berimplikasi pada beragamnya bahasa daerah di wilayah nusantara ini. Keberadaan bahasa Indonesia sebagai bahasa persatuan, tidak terlepas dari peran bahasa daerah sebagai pilar utama bahasa Indonesia dan salah satu unsur kebudayaan nasional, sebagaimana tercantum dalam UUD 1945 pasal 36 Bab XV mengenai kedudukan bahasa Indonesia sebagai bahasa resmi atau bahasa negara, yang berbunyi "Bahasa daerah merupakan bagian dari kebudayaan Indonesia yang hidup; bahasa daerah adalah salah satu unsur kebudayaan nasional yang dilindungi oleh negara". Oleh karena itu, keberadaan bahasa daerah harus dipertahankan dan diberdayakan secara maksimal agar kontribusinya kepada bahasa nasional lebih tampak. (Kompas.com, 20/9/2009)

Salah satu kontribusi besar bahasa daerah terhadap bahasa Indonesia adalah memperbanyak kosa kata. Telah banyak bahasa daerah yang diserap menjadi bahasa Indonesia. Dari 90.000 kosakata yang terekam dalam Kamus Besar Bahasa Indonesia edisi ke-4, sebanyak 3.631 kosakata berasal dari 72 bahasa daerah antara lain, bahasa Jawa, Minangkabau, Sunda, Bali, Aceh, Batak dan bahasa Lampung. (Kompas, 30 September 2009)

Salah satu peran bahasa daerah terhadap bahasa Indonesia adalah memberikan kontribusi dalam penambahan kosa kata. Kebutuhan penambahan kosa kata bahasa daerah untuk Kamus Besar bahasa Indonesia setiap tahunnya sebanyak 2.000 kosa kata (bisnis.com, 28 Agustus 2017) Bahasa Sunda memiliki kontribusi kepada bahasa Indonesia dengan menambakan 223 kosa kata (kompas.com, 30 September 2009)

Pemerintah Indonesia berencana menjadikan bahasa Indonesia sebagai bahasa Internasional. Untuk mewujudkan hal tersebut, maka pemerintah telah membentuk 250 Pusat Bahasa Indonesia untuk Penutur Asing (BIPA) yang tersebar di berbagai negara di lima benus (republika.co.id). Keinginan pemerintah menjadikan bahasa Indonesia sebagai bahasa Internasional tidak terlepas dari fakta yang menunjukkan bahwa bahasa Indonesia telah banyak digunakan di berbagai negara di dunia. Di kawasan ASEAN, pengguna bahasa Indonesia memiliki penutur terbanyak di Asia Tenggara. Bahasa Indonesia pun sudah dipakai sebagai bahasa resmi sidang ASEAN dan menjadi bahasa kerja di Timor Leste (republika.co.id, 5 April 2017). 
Memasuki era Masyarakat Ekonomi ASEAN (ASEAN Economic Community), bahasa Indonesia diharapkan dapat menjadi bahasa resmi ASEAN yang akan selalu dipakai dalam setiap pertemuan negara-negara anggota ASEAN. Di sisi lain, kenyataan menunjukkan, bahasa yang sering digunakan dalam pertemuan antarnegara ASEAN adalah bahasa Inggris. Kondisi ini, tentunya patut menjadi perhatian agar jangan sampai keinginan untuk menjadikan bahasa Indonesia sebagai bahasa komunikasi resmi ASEAN terkikis perlahan oleh seringnya bahasa Inggris digunakan oleh para anggota ASEAN. Akibatnya, bukan tidak mungkin, dominasi bahasa Inggris terhadap bahasa Indonesia, akan berimbas pada bahasa daerah.

Fungsi dari bahasa daerah tercantum pada kesimpulan Seminar Politik Bahasa Nasional tahun 1975 di Jakarta, yang menyatakan bahwa bahasa daerah mempunyai fungsi sebagai lambang kebanggaan daerah, sebagai lambang identitas daerah, dan juga alat komunikasi dalam masyarakat daerah.

Dalam hubungannya dengan fungsi bahasa Indonesia, bahasa daerah berfungsi sebagai pendukung bahasa nasional, sebagai bahasa pengantar pada pendidikan tingkat sekolah dasar, sumber kebahasaan, serta sebagai pelengkap bahasa Indonesia.

1. Pendukung Bahasa Nasional; Kongres Bahasa Indonesia ke II yang diadakan tahun 1954 di Medan menjelaskan bahwa bahasa daerah sebagai pendukung bahasa nasional. Bahasa daerah memberikan pengaruh pada bidang morfolog, fonologi, sintaksis, dan kosa kata kepada bahasa Indonesia. Sebaliknya, bahasa Indonesia pun memberikan pengaruh terhadap perkembangan suatu bahasa daerah. Jadi bahasa daerah dan bahasa Indonesia itu saling melengkapi dalam proses perkembangannya.

2. Sebagai Bahasa Pengantar; Bahasa daerah merupakan bahasa pengantar pada pendidikan tingkat sekolah dasar di wilayah tertentu, juga sebagai alat komunikasi masyarakat suatu daerah untuk saling menyampaikan informasi. Terkadang banyak anak yang dibiasakan dengan bahasa daerah sehingga belum terlalu mengerti ketika awal memasuki sekolah jika menggunakan bahasa Indonesia. Oleh karena itu 3 tahun pertama menggunakan bahasa pengantar bahasa daerah, selanjutnya menggunakan bahasa Indonesia sebagai bahasa pengantar dalam proses pembelajarannya.

3. Sumber Kebahasaan; Bahasa daerah merupakan sumber kebahasaan yang berfungsi untuk memperkaya bahasa Indonesia berupa penambahan kosa kata berupa istilah untuk sesuatu yang belum ada istilahnya dalam bahasa Indonesia. Contohnya ngabuburit, untuk menyebut aktivitas yang dilakukan menjelang berbuka puasa pada saat bulan Ramadhan. Atau kata gethuk untuk menyebut makanan berbahan dasar umbi yang direbus dan dicampurkan dengan gula dan kelapa, lalu di tumbuk secara bersama.

4. Pelengkap Bahasa Indonesia; Bahasa daerah berfungsi sebagai pelengkap bahasa Indonesia dalam penyelenggaran suatu pemerintahan pada tingkat daerah. Dalam suatu pemerintahan tingkat daerah, bahasa daerah masih dijadikan sebagai alat komunikasi ketika diadakan komunikasi antara pemerintah dengan warga.

Dalam kaitan dengan pemertahanan bahasa-bahasa Nusantara, baik bahasa-bahasa besar yang memiliki tradisi tulis masa lalu dan dukungan penutur berjumlah besar maupun bahasa-bahasa kecil yang tidak memiliki tradisi tulis dan hanya didukung oleh penutur berjumlah kecil, umumnya berada dalam kondisi keterancaman yang nyaris sama, meski kualitas ancamannya berbeda-beda. Transmisi bahasa bernilai tradisi lokal dari generasi tua kepada generasi muda tersendat-sendat bahkan tidak jelas (Sutjaja, 2006:3). Ancaman umum kepunahan bahasa-bahasa lokal, sangat jelas berpangkal pada sikap kurangnya apresiasi dan rendahnya mutu penggunaan bahsa lokal generasi pewaris dan penerus bahasa, sastra dan budaya Nusantara (Mbete,2009) 
Bahasa Sunda adalah bahasa yang digunakan sebagian besar penduduk Jawa Barat, termasuk di Kota Bandung. Berdasarkan penelitian Summer Institute of Linguistics (SIL), penutur bahasa Sunda merupakan yang terbanyak kedua di Indonesia setalah bahasa Jawa dengan 27 juta penutur. Namun demikian, terdapat kekhawatiran dari berbagai pihak akan punahnya bahasa daerah termasuk Bahasa Sunda, yang penggunanya terus berkurang akibat perkembangan zaman yang mengikis kecintaan terhadap bahasa daerah.

Pada Bahasa Sunda, empat puluh persen masyarakat Jawa Barat dikabarkan tidak bisa menggunakan Bahasa Sunda (Koran Tempo, 22 Februari 2008) dan di Kota Bandung, diperkirakan penggunanya tinggal 30 persen, itupun terbatas pada siswa-siswa sekolah yang belajar Bahasa Sunda Di kota besar seperti Bandung, kekhawatiran tersebut beralasan, karena, semakin banyak orang tua, terutama ibu-ibu muda yang tidak mau menggunakan Bahasa Sunda dalam percakapan sehari-hari, karena Bahasa Sunda dianggap tidak intelek, tidak sesuai dengan kebutuhan teknologi. Malah banyak orang tua yang melarang anaknya menggunakan Bahasa Sunda karena takut Bahasa Sundanya kasar. Akibatnya, orang lebih suka dan bangga menggunakan Bahasa Indonesia daripada Bahasa Sunda sehingga Bahasa Sunda menjadi bahasa kedua setelah Bahasa Indonesia. (Pikiran Rakyat, 15 Februari 2007).

Berdasarkan fungsinya pada bahasa Indonesia, maka bahasa daerah penting untuk dilestarikan, karena bahasa merupakan salah satu hasil dari kebudayaan seperti yang disampaikan oleh Koentjaraningrat. Selain itu bahasa juga merupakan alat komunikasi yang dapat mentransmisikan kebudayaan kepada khalayak luas.

Edward T. Hall dalam Mulyana dan Solatun (2007: 88) mengatakan bahwa communication is culture and culture is communication. Budaya dan komunikasi tidak dapat dipisahkan, karena budaya tidak hanya menentukan siapa yang bicara dengan siapa, tentang siapa, tentang apa dan bagaimana orang memaknai pesan. Budaya merupakan landasan komunikasi. Apabila budaya beraneka ragam, maka beraneka ragam pula praktik-praktik komunikasi (Mulyana, 2006: 18).

Banyak cara yang dapat dilakukan untuk menjaga keberlangsungan penggunaan bahasa daerah dalam kehidupan bermasyarakat. Aron Meko Mbete dari Universitas Udayana, dalam tulisannya "Strategi Pemertahanan Bahasa-Bahasa Nusantara" (2010) mengemukakan 5 konsep pemertahanan bahasa di Nusantara, yakni (1) pemantapan kedwibahasaan, (2) keterjalinan substansi pendidikan, penelitian dan pengabdian kebahasaan, (3) pengembangan kerjasama antarjurusan kebahasaan di perguruan tinggi dengan lembaga-lembaga masyarakat, (4) penerjemahan, penulisan dan teknologisasi khazanah sastra dan budaya Nusantara, serta (5) reorientasi kebahasaan dan kebudayaan.

Dalam penelitian ini, salah satu cara yang digunakan untuk melestarikan bahasa Sunda sebagai bagian dari kebudayaan adalah melalui tulisan. Para penulis tersebut masih konsisten menghasilkan karya tulis dalam bahasa Sunda, meski secara ekonomi, honor tulisan yang diterima tidak sebanding dengan proses kreatifitas yang dihasilkan.

Tulisan ini bertujuan untuk mengungkapkan upaya penulis Sunda dalam melestarikan bahasa dan budaya Sunda melalui tulisan, serta motif mereka untuk bertahan menulis dalam bahasa Sunda.

\section{Metode Penelitian}

Penelitian ini bertujuan untuk mengungkapkan upaya yang dilakukan penulis Sunda dalam melestarikan bahasa Sunda melalui tulisan, serta motif mereka untuk bertahan menulis dalam bahasa Sunda. Penelitian ini menggunakan metode kualitatif dengan pendekatan fenomenologi. Menurut Polkinghorne dalam Creswell (1998: 51-52), penelitian kualitatif dengan pendekatan fenomenologi menggambarkan makna pengalaman hidup sejumlah individu tentang konsep fenomena. Fenomenologis menggali struktur kesadaran dalam 
pengalaman manusia ("A phenomenological study describes the meaning of the lived experience for several individuals abaut a concept or the phenomenon. Phenomenologist exsplore the structure of conciousness in human experience").

Dalam tulisan ini, konsep fenomena yang dimaksud adalah masih adanya penulis yang konsisten menulis dalam bahasa Sunda meskipun kondisi penerbitan dan jumlah pembacanya tidak begitu menggembirakan. Metode ini digunakan untuk memperoleh gambaran mendalam mengenai pengalaman informan melestarikan bahasa Sunda melalui karya yang dihasilkannya, serta mengungkapkan motif dan makna dari upaya pelestarian bahasa Sunda yang dilakukannya.

Subjek penelitian ini adalah penulis yang menuangkan pikiran dan perasaan mereka mengenai kasundaan atau hal lainnya, yang ditulis dalam bahasa Sunda dan disampaikan melalui media massa, buku, media sosial dan film (Susanti, 2011). Delapan informan dipilih secara purposif untuk mendukung penelitian yang dilakukan berdasarkan kompetensinya sebagai seorang penulis, yang dapat mendukung tujuan penelitian, yaitu menggambarkan pengalamannya melestarikan bahasa Sunda melalui hasil karyanya. Kriteria tersebut yaitu a) Secara umum dikenal sebagai Penulis Sunda, baik menulis dalam Bahasa Sunda maupun menulis tentang kasundaan, b) Banyak hasil karya tulisan mereka yang dipublikasikan, c) Hasil karya tulisnya masih tetap ada, bahkan banyak melahirkan ide-ide baru dalam menghasilkan karya.

Mereka adalah penulis yang masih aktif dan tinggal di Kota Bandung, lokasi yang mudah untuk diakses sesuai dengan saran Creswell. Para penulis merupakan jurnalis dan mantan jurnalis yang aktif menulis dalam bahasa Sunda maupun bahasa Indonesia. Mereka adalah Us Tiarsa, Usep Romli, Aam Amilia, Aan Merdeka Permana, Eddy D. Iskandar, Taufik Faturohman, Hawe Setiawan dan Dadan Sutisna.

Teknik pengumpulan data dilakukan melalui wawancara mendalam dan observasi nonpartisipatif kepada informan penulis, serta kajian dokumentasi yang relevan dengan penelitian, yang diperoleh dalam bentuk buku, artikel majalah dan surat kabar, berita di internet, serta pengamatan pada media sosial para penulis.

Penelitian ini menggunakan teori Fenomenologi dan teori Tindakan Sosial Max Weber. Menurut teori fenomenologi, realitas dikonstruksi menurut sudut pandang subyek yang dijadikan partisipan penelitian. Peneliti sebagai instrumen penelitian, mencoba merangkai pengalaman subyek yang diteliti menjadi realitas yang ditemukan sesuai sudut pandang mereka.

Menurut Polkinghorne (dalam Creswell, 1998:51), penelitian fenomenologi mencoba menjelaskan atau mengungkap makna konsep atau fenomena pengalaman yang didasari kesadaran yang terjadi pada beberapa individu. Penelitian dilakukan dalam situasi yang alami, sehingga tidak ada batasan dalam memaknai atau memahami fenomena yang dikaji. Teori Tindakan Sosial (social action theory), dicetuskan Max Weber, seorang perintis sosiologi di Jerman. Menurut Weber, tindakan sosial merupakan semua perilaku individu yang memiliki makna subjektif bagi dirinya dan diarahkan kepada tindakan orang lain (Weber dalam Ritzer, 2004). Tindakan di sini bisa terbuka atau tersembunyi, bisa merupakan intervensi positif dalam suatu situasi atau sengaja berdiam diri sebagai tanda setuju dalam situasi tersebut.

Bagi Weber, perilaku manusia pada dasarnya bermakna, melibatkan penafsiran, berpikir dan disengaja, baik orang lain maupun bagi sang aktor sendiri, yang pikiranpikirannya aktif saling menafsirkan perilaku orang lain, berkomunikasi satu sama lain dan mengendalikan perilaku dirinya masing-masing sesuai maksud komunikasinya. Penelitian ini menggunakan sejumlah konsep yang terkait dengan peran penulis dalam pelestarian budaya Sunda. 


\section{HASIL PENELITIAN DAN PEMBAHASAN}

Keberadaan penulis Sunda merupakan realitas yang ada dalam lingkungan masyarakat Sunda. Mereka merupakan harapan akan keberlangsungan bahasa Sunda sebagai media komunikasi untuk menyampaikan informasi kepada khalayak. Para penulis Sunda yang menjadi informan penelitian ini merupakan jurnalis dan mantan jurnalis di media yang ada di Jawa Barat. Mereka mampu untuk menulis tulisan fiksi dan nonfiksi sebagai bentuk penyampaian ide atau informasi kepada khalayak pembacanya, termasuk gagasan dalam bentuk tulisan mengenai budaya Sunda yang disampaikan dalam bahasa Sunda melalui beragam media yang dipilih sesuai kemampuan penulis.

Para penulis Sunda di Kota Bandung melakukan hal tersebut untuk memelihara bahasa dan kebudayaan Sunda. Para penulis adalah pemilik bahasa yang ingin menjaga keberlangsungan bahasa dan budaya yang mereka akrabi sejak kecil agar tetap dikenal dan digunakan.

\section{Menulis sebagai Idealisme Memelihara Bahasa dan Budaya Sunda}

Para penulis Sunda yang menjadi informan penelitian ini adalah orang Sunda yang lahir dan besar di tanah Pasundan. Tumbuh bersama bahasa dan budaya Sunda yang mereka akrabi sejak kecil telah memunculkan kesadaran bahwa mereka adalah pemilik budaya yang memiliki kewajiban untuk melestarikan bahasa dan budaya Sunda agar tetap dikenal dan digunakan oleh generasi berikutnya. Idealisme inilah yang kemudian menjadi motif bagi sebagian besar individu informan penelitian ini meleteslatikan bahasa dan budaya Sunda. Bagi Us Tiarsa, pemimpin redaksi Bandung TV, keberadaannya sebagai Penulis Sunda yang menghasilkan tulisan dalam Bahasa Sunda dan tentang kesundaan merupakan keinginannya pribadi sebagai orang Sunda yang ingin memelihara bahasa Sunda. "Tujuan idealnya untuk memelihara Bahasa Sunda. Saya berkewajiban untuk memelihara itu dan saya ingin memelihara itu"

Salah satu upaya untuk memelihara Bahasa Sunda tersebut, dilakukan Us Tiarsa dengan menulis dalam Bahasa Sunda yang baik dan benar ketika menulis cerita fiksi dan nonfiksi.

"Melalui cerita pendek atau lainnya, orang akan ngeh, oh ini bahasa saya. Saya tidak pernah menuliskan satu kata yang sebetulnya kata itu bukan kata Sunda misalnya. Saya berusaha sekuat tenaga, bahasa saya adalah Bahasa Sunda yang baik dan benar. Tidak pernah bercampur dengan bahasa lain".

Demikian pula beberapa penulis yang secara konsisten menulis dalam bahasa Sunda berdasarkan idealisme ingin melestarikan bahasa Sunda.

"Walaupun humor, yang pertama, saya punya idealisme. Jadi masyarakat, baik orang tua, remaja maupun anak-anak harus cinta Basa Sunda". (Taufik Faturohman, penulis humor)

"Kalau kita meninggalkannya karena salah satu alasannya tidak ada nilai komersilnya, tidak bisa mendatangkan apa-apa secara materi, ya punahlah sudah. Jadi, berkarya itu bagi saya untuk sebatas memperpanjang fungsi-fungsi Bahasa Sunda terutama dalam bentuk tulisan". (Dadan Sutisna, penulis fiksi)

Melestarikan berarti memelihara untuk waktu yang sangat lama. Oleh karena itu, pelestarian harus dilakukan secara berkelanjutan (sustainable) dan bukan pelestarian sesaat tanpa akar yang kuat di masyarakat. Pelestarian tidak akan dapat bertahan dan berkembang jika tidak didukung oleh masyarakat luas dan tidak menjadi bagian nyata dari kehidupan kita. Pelestarian harus hidup dan berkembang di masyarakat. Pelestarian harus diperjuangkan oleh masyarakat luas (Hadiwinoto, 2002: 30). 
Pelestarian akan sustainable jika berbasis pada kekuatan dalam, kekuatan lokal, kekuatan swadaya. Karenanya sangat diperlukan penggerak, pemerhati, pecinta dan pendukung dari berbagai lapisan masyarakat. Untuk itu perlu ditumbuhkembangkan motivasi yang kuat untuk ikut tergerak berpartisipasi melaksanakan pelestarian, antara lain: 1) Motivasi untuk menjaga, mempertahankan dan mewariskan warisan budaya yang diwarisinya dari generasi sebelumnya; 2) Motivasi untuk meningkatkan pengetahuan dan kecintaan generasi penerus bangsa terhadap nilai-nilai sejarah kepribadian bangsa dari masa ke masa melalui pewarisan khasanah budaya dan nilai-nilai budaya secara nyata yang dapat dilihat, dikenang dan dihayati; 3) Motivasi untuk menjamin terwujudnya keragaman atau variasi lingkungan budaya; 4) Motivasi ekonomi yang percaya bahwa nilai budaya local akan meningkat bila terpelihara dengan baik sehingga memiliki nilai komersial untuk meningkatkan kesejahteraan pengampunya; dan 5) Motivasi simbolis yang meyakini bahwa budaya lokal adalah manifestasi dari jatidiri suatu kelompok atau masyarakat sehingga dapat menumbuhkembangkan rasa kebanggaan, harga diri dan percaya diri yang kuat.(Karmadi, 2007)

Berdasarkan penjelasan tersebut, pelestarian budaya lokal memiliki muatan ideologis yaitu sebagai gerakan untuk mengukuhkan kebudayaan, sejarah dan identitas (Lewis, 1983: 4), dan juga sebagai penumbuh kepedulian masyarakat untuk mendorong munculnya rasa memiliki masa lalu yang sama diantara anggota komunitas (Smith, 1996: 68).

\section{Menulis sebagai Transmisi Pesan Pelestarian Budaya}

Sarah Trenholm dan Arthur Jensen dalam Wiryanto (2004: 6), mengartikan komunikasi sebagai proses mentransmisikan pesan dari sumber kepada penerima melalui beragam saluran. Tulisan merupakan salah satu saluran penyampai pesan, sebagai hasil penciptaan atau kreasi dari seorang penulis, yang dapat diinformasikan dan disosialisasikan kepada orang lain. Melalui bahasa, para penulis mengonstruksi realitas sebagai suatu pesan yang dikomunikasikan kepada pembacanya.

Dalam konteks para penulis, komunikasi disampaikan melalui media sehingga disebut komunikasi bermedia (mediated communication). Media komunikasi yang digunakan para penulis Sunda, cukup beragam. Akan tetapi, sebagian besar masih mengandalkan media cetak, seperti surat kabar, tabloid, majalah dan buku. Melalui media inilah, para penulis menyampaikan pikiran dan perasaannya dengan menggunakan bahasa secara tertulis.

Merujuk apa yang disampaikan oleh Hamid Hasan Lubis, dalam menyampaikan tulisannya pun, para penulis mempertimbangkan konteks situasi dan kondisi yang dihadapinya, sehingga tulisannya bisa dikemas sedemikian rupa, supaya enak dibaca, memiliki konteks kekinian dan bisa dipahami oleh pembaca dengan mudah, sehingga apa yang ingin disampaikannya dapat dipahami dengan baik.

Menurut Dadan, menulis dalam bahasa Sunda masih dibutuhkan sebagai bentuk pelestarian bahasa. Alasannya,

"Salah satu ciri bahasa itu masih hidup dengan baik adalah yang pertama dilihat dari sisi panyatur, penutur. Kemudian dilihat juga, apakah bahasa itu cuma hidup dalam bahasa lisan atau juga hidup dalam bahasa tulisan. Kalau bahasa lisan, saya yakin di perkampungan itu sampai sekarang masih menggunakan Bahasa Sunda. tapi ketika kita berbicara masalah bahasa tulisan, yang dibutuhkan adalah penulis-penulis berbahasa Sunda, baik fiksi maupun nonfiksi"

Harapan Dadan untuk dapat mengembangkan Bahasa Sunda, ia lakukan dengan memperkaya tema-tema tulisan sesuai perkembangan jaman. Salah satunya dengan memasukkan unsur-unsur teknologi informasi, bidang yang ia sukai sejak tahun 2000-an, ke dalam tema-tema tulisan fiksi dan nonfiksi yang ditulisnya. Dalam tulisan fiksi, karya Dadan 
antara lain novel anak bertema detektif berjudul Rasiah Kodeu Biner, yang mendapatkan Hadiah Sastra Rancage di tahun 2011 dan puisi berjudul Sasemplek Potret JPEG.

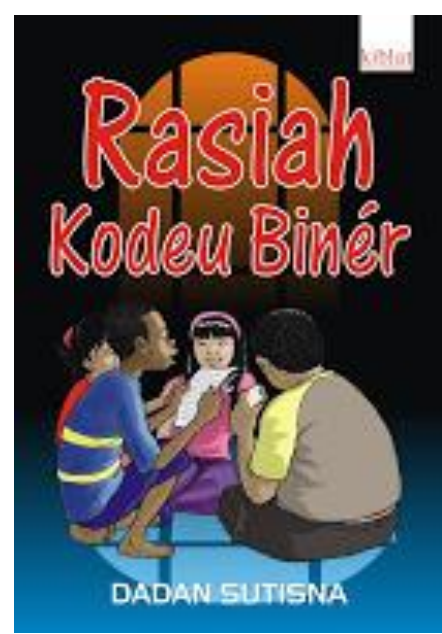

Gambar 1

Rasiah Kodeu Biner, novel anak bertema detektif dan teknologi informasi karya Dadan Sutisna, yang mendapatkan hadiah Sastra Rancage dari Yayasan Kebudayaan Rancage

(sumber: http://kiblatbukusunda.blogspot.co.id)

Secara garis besar, tema-tema yang dipilih para penulis dalam menyampaikan pesan mengenai pelestarian bahasa dan budaya Sunda ditampilkan dalam tabel berikut:

Tabel 1. Pemilihan Tema

\begin{tabular}{|l|l|l|}
\hline & \multicolumn{1}{|c|}{ Tema } & \multicolumn{1}{c|}{ Informan } \\
\hline 1 & Sosial & Us Tiarsa, Aam Amilia, Dadan Sutisna \\
\hline 2 & Peristiwa Aktual & Usep Romli \\
\hline 3 & Sejarah Klasik Sunda & Aan Merdeka Permana \\
\hline 4 & Dunia Remaja/Populer & Eddy D. Iskandar \\
\hline 5 & Humor & Taufik Faturohman \\
\hline 6 & Kearifan Lokal Sunda & Hawe Setiawan \\
\hline
\end{tabular}

Us Tiarsa, yang berlatar belakang jurnalis, memilih tema sosial dan tentang manusia, yang dekat dengan kehidupan sehari-hari, untuk lebih banyak dituangkan ke dalam tulisannya. Pemilihan tema tersebut karena ia merasa mampu untuk menuliskannya. "Ya itu kehidupan kita sehari-hari dan saya mampu menulis itu saja. Tidak menulis apa-apa yang tidak saya ketahui".

Tulisan tema sosial yang dihasilkannya disampaikan dalam bentuk carita pondok, artikel, puisi serta menulis esei dalam Bahasa Sunda dan Bahasa Indonesia, yang dimuat di beberapa media cetak, seperti Galura, Mangle, Pikiran Rakyat dan Kompas. $\quad$ Karya Us dengan tema sosial yang mendapat penghargaan adalah kumpulan cerpen berjudul Halis Pasir yang mendapatkan hadiah Sastra Rancage tahun 2011. "Itu menceritakan tentang seorang nenek yang masih bekerja sebagai pembuat batu bata dalam usianya yang sudah renta," ujar Us.

Sama dengan Us Tiarsa, satu-satunya informan perempuan dalam penelitian ini, Aam Amilia, menyebut tema sosial sebagai tema yang sering diterapkan dalam tulisannya. Hal itu dilatarbelakangi oleh pengalamannya sebagai wartawan, yang pernah ditugaskan untuk meliput peristiwa dalam berbagai bidang, yang memperkaya tema-tema tulisannya. Rupanya, 
bidang sosial lebih menarik perhatiannya daripada bidang-bidang yang lain. Ketika ditanya alasannya memilih tema sosial, Aam beralasan,

"Da naon atuh ari nyaritakeun keluarga wae mah teu rame. Harus ada kaluar. Mimiti keluarga...,budaya. Ibu mah da sekitar eta weh. Sosial, budaya, kasehatan kapungkur mah".

("Kalau terus nyeritain keluarga mah nggak rame. Harus keluar. Awalnya keluarga, budaya. Sekitar itu aja. Sosial, budaya, kesehatan, kalau dulu”..)

Demikian halnya dengan informan Dadan Sutisna, yang menulis tema-tema sosial dari peristiwa sehari-hari yang dilihat dan dialaminya, terutama untuk penulisan cerpen. Dadan lebih sering menulis cerpen dengan latar kehidupan orang-orang kelas bawah yang dianggapnya lebih mewakili keinginannya untuk menyampaikan realitas dari kehidupan orang-orang bawah. "Kalau pun saya menulis dari sisi sosial kelas atas, mungkin lebih cenderung ke bentuk kritikan, ” ujar Dadan.

Sementara itu, Usep Romli lebih menyukai tema-tema aktual yang bersumber dari peristiwa yang terjadi di masyarakat, untuk dijadikan tema tulisannya, baik bidang politik, ekonomi, sosial, budaya dan lainnya. Pemilihan tema tersebut terkait dengan latar belakang Usep yang sering membaca buku-buku tentang politik, budaya dan bidang lainnya semasa kecil, ketika ia sering berkunjung ke rumah tetangganya di Garut untuk membaca buku berbagai tema, yang membuka kesadarannya untuk think globally, act locally.

Menulis cerita dengan tema sejarah klasik Sunda, merupakan kegiatan yang dilakukan oleh Aan Merdeka Permana sejak tahun 1989. Hasratnya yang menggebu untuk menemukan jejak sejarah klasik Sunda yang hilang membuatnya rela untuk merogoh koceknya sendiri untuk membuat majalah soal sejarah Sunda, yaitu Ujung Galuh. Tentang pilihan tema tulisannya, Aan beralasan, ia merasa haus dengan berita-berita masa lalu sejarah Sunda, yang dinilainya sangat kurang.

Pilihan tema tentang Sejarah Sunda, membawa konsekuensi bagi Aan untuk melakukan investigasi mencari informasi yang dibutuhkannya sampai ke daerah-daerah. Jangkauan terjauh dari investigasi Aan adalah wilayah Bubat di Jawa Timur untuk menulis tentang Perang Bubat.

Sementara itu, Eddy D. Iskandar memilih tema yang fleksibel, terutama yang terkait dengan dunia remaja, hal yang sejak dulu dikuasainya ketika menulis dalam Bahasa Indonesia. Untuk tema, Eddy menyesuaikan dengan perkembangan jaman. Ia menuliskan lebih banyak kehidupan masa kini untuk dapat menyampaikan Budaya Sunda pada anak muda. Eddy mencontohkan, ia pernah membuat novelet berjudul Cinta Pabaliut.

"Itu saya buat bukan karena ingin menulis remaja dalam Bahasa Sunda, karena ada satu kesadaran, ingin ada pembaca remaja menyimak sesuatu. Karena tokohnya itu remaja yang senang Cianjuran, satu kesenian tradisi. Tapi, saya gunakan bahasabahasa remaja, walaupun tidak intensif. Tapi beberapa remaja yang baca itu ada yang menangis dan ada bapaknya yang berterima kasih karena setelah anaknya membaca buku itu, keinginannya kepada tradisi jadi besar".

Sedangkan bagi Taufik Faturohman, tema yang menjadi pilihannya dalam tulisan adalah Humor Sunda. Tema ini dikuasainya, karena ia banyak membaca buku-buku humor sejak kecil. Taufik mengaku, di kamarnya tersebar buku, baik di rak buku maupun di tempat tidurnya, supaya menjelang tidur, ia bisa segera membaca buku humor, sebagai salah satu nutrisi untuk penulisannya. "Mungkin di kepala saya ini sekitar tiga ribuan lah joke-joke Sunda itu. Dan hapal, karena tiap hari dipakai”. 
Selain itu, pemilihan tema didasarkan pada strategi pasar yang memberikan pilihan pada pembaca untuk menentukan bahan bacaan yang diinginkan.

"Ketika sekarang orang jenuh dengan berita politik, berita ekonomi, yang kian hari tidak menentu, dengan humor banyak yang senang. Dan karakteristik orang Sunda itu kan tidak bisa lepas dari humor. Ketika ada duabelas orang lagi jalan bersama, nu pang katinggalina huntu (gigi-pen) pasti orang Sunda. Semuanya bisa jadi humor".

Tulisan dalam bentuk Humor Sunda sudah dibukukannya hingga delapan buku, dengan jumlah humor yang terangkum sebanyak empat ribuan. Di luar itu, Taufik pun rajin menulis tentang buku Pengajaran Bahasa Sunda, yang menjadi sumber penghasilan utamanya selama ini, yang diterbitkan oleh Penerbit Geger Sunten yang didirikannya.

Sedangkan Hawe Setiawan, dalam setiap kali menulis, selalu beranjak dari hal-hal kecil yang dilihat dan dirasakannya. Ia selalu berupaya untuk menyertakan kearifan lokal Sunda yang dikaitkan dengan kehidupan global. Hal tersebut sesuai dengan tujuannya menulis tentang kesundaan, yaitu mengenalkan Budaya Sunda secara luas dalam tataran global dunia.

"Abdi selalu berupaya untuk mempertautkan kearifan lokal dengan persoalan global. Bisa nggak kebudayaan Sunda itu diangkat, dibicarakan, dalam hubungannya dengan persoalan sejagat dalam menghadapi krisis lingkungan”.

Untuk pengangkatan tema, dengan konsep seperti itu, maka apapun bisa menjadi tema tulisan, dengan beranjak dari hal yang kecil, terus dikembangkan menjadi hal yang global.

Regenerasi merupakan cara yang bisa ditempuh dalam mentransmisikan kemampuan menulis dalam bahasa Sunda kepada generasi berikutnya, seperti yang dilakukan oleh Aam Amilia, perempuan penulis yang telah berhasil mendidik para penulis Sunda yang sekarang aktif menulis dalam bahasa Sunda. Beberapa penulis yang sempat jadi anak asuhnya adalah Taufik Faturohman, Holisoh ME, Cecep Burdansyah dan Hermawan Aksan.

\section{SIMPULAN}

Penulis Sunda merupakan pelaku dalam kesusasteraan daerah yang muncul dari adanya kesadaran untuk menyampaikan pikiran dan perasaannya tentang realitas budaya Sunda yang dihadapinya ke dalam Bahasa Sunda. Kiprah mereka sebagai Penulis Sunda lebih pada idealisme sebagai urang Sunda yang ingin memberikan kontribusi pada budayanya untuk tetap bertahan, di tengah gerusan perkembangan zaman, yang perlahan menggeser Budaya Sunda dari posisinya, digantikan budaya yang lebih global.

Prinsip mengikuti zaman harus menjadi pedoman bagi setiap pembicara bahasa asli sebuah wilayah. Sebab, dengan kemampuan menyesuaikan diri, maka keberadaan bahasa daerah dapat terus dipertahankan.

Suatu bahasa atau budaya akan dapat bertahan jika penggunanya masih ada. Kontribusi bahasa Sunda sebagai bahasa daerah pada bahasa Sunda, turut memperkaya bahasa Indonesia, yang ditargetkan oleh pemerintah untuk menjadi bahasa resmi komunikasi ASEAN di era Masyarakat Ekonomi ASEAN.

Saran dari penelitian ini, selanjutnya dapat dilakukan penelitian dengan metode lain, misalnya metode survey untuk mengukur sejauh mana efektifitas tulisan dalam bahasa Sunda berpengaruh terhadap pengetahuan tentang budaya Sunda.

\section{REFERENSI}

Aron, M.M. (2010). Strategi Pemertahanan Bahasa-Bahasa Nusantara. Seminar Nasional Pemertahanan Bahasa Nusantara di Undip Semarang (2010). 
Bisnis.com, 28 Agustus 2017. 2.000 Kosakata Bahasa Daerah Perlu Masuk KBBI. http://kabar24.bisnis.com/read/20170828/255/684956/2.000-kosa-kata-bahasadaerah-perlu-masuk-kbbi

Budhisantoso, S. (1990). Kondisi dan Masalah Budaya Sunda Dewasa Ini. Jakarta: Depdikbud

Creswell, John W. (1998). Qualitative Inquiry and Research Design: Choosing Among Five Traditions. USA: Sage Publication Inc.

Kompas.com, 30 September 2009. Bahasa Daerah Menjadi Pilar Utama Bahasa Indonesia.http://regional.kompas.com/read/2009/09/30/01320043/bahasa.daerah.men jadi.pilar.utama.bahasa.indonesia.

Lubis, A. Hamid Hasan. (1993). Analisis Wacana Pragmatik. Bandung: Angkasa.

Mbete, A.M. (2009). "Bahasa dan Budaya Lokal Minoritas: Asal Muasal, Ancaman Kepunahan dan Ancangan Pemberdayaan dalam Kerangka Pola Ilmiah Pokok Kebudayaan" dalam Wayan Windia et al. (editor). Pemikiran Kritis Guru Besar Universitas Udayana, Bidang Sastra dan Budaya. Denpasar: Universitas Udayana. http://eprints.undip.ac.id/36865/1/1.pdf

Mulyana, Deddy dan Solatun. (2007). Metode Penelitian Komunikasi. Contoh-contoh Penelitian Kualitatif dengan Pendekatan Praktis. Bandung: Remaja Rosdakarya.

Nababan, Freddy. Antara bahasa daerah, Indonesia dan asing. https://www.tobawriters.com/antara-bahasa-daerah-indonesia-dan-asing 18/9/2017

Pemerintah Merancang Bahasa Indonesia sebagai Bahasa Internasional. Republika.co.id, 5 April 2017. http://nasional.republika.co.id/berita/nasional/umum/17/04/05/ ony3q1383- pemerintah-sedang-menjadikan-bahasa-indonesia-sebagai-bahasainternasional

Ritzer, George. 2004. Teori Sosiologi Modern. Jakarta: Kencana.

Sutjaja, I Gusti Made. (2006). Endangered Languages of the World

Wiryanto. (2004). Pengantar Ilmu Komunikasi. Jakarta: Gramedia Widiasarana Indonesia

\section{Sumber lain:}

Dadan Sutisna. (2008). Peringkat Bahasa Sunda. Kompas Jawa Barat, Sabtu, 5 April 2008.

Dingding Haerudin. (2005) Meningkatkan Kesadaran Berbahasa Sunda. Pikiran Rakyat, 19 Februari 2005

Kompas, 14 Februari 2010.

Koran Tempo, 22 Februari 2008.

Pikiran Rakyat, 15 Februari 2007. 